\title{
Nantucket Pine Tip Moth, Rhyacionia frustrana (Comstock) (Insecta: Lepidoptera: Tortricidae) ${ }^{1}$
}

Wayne N. Dixon ${ }^{2}$

\section{Introduction}

The Nantucket pine tip moth, Rhyacionia frustrana (Comstock), is a serious pest of young pine in plantations, wild pine seedlings in open areas, Christmas tree plantings, ornamental pines, and pine seed orchards in the United States. Growth loss and stem deformity, caused by larvae feeding inside growing shoots, buds, and conelets, can be considerable during the first five years when most damage occurs (Yates et al. 1981). The increasing population of a preferred host species, loblolly pine (Pinus taeda L.), in Florida poses an ever-increasing problem of Nantucket pine tip moth infestations.

\section{Distribution}

The second most widely distributed native North American member of the genus, $R$. frustrana occurs from Massachusetts south to Florida, and west to Missouri, Oklahoma, Texas and California. It is also found in the Dominican Republic, Cuba, Jamaica, Mexico (Oaxaca), Guatemala, Honduras and Nicaragua (Powell and Miller 1978). The infestation

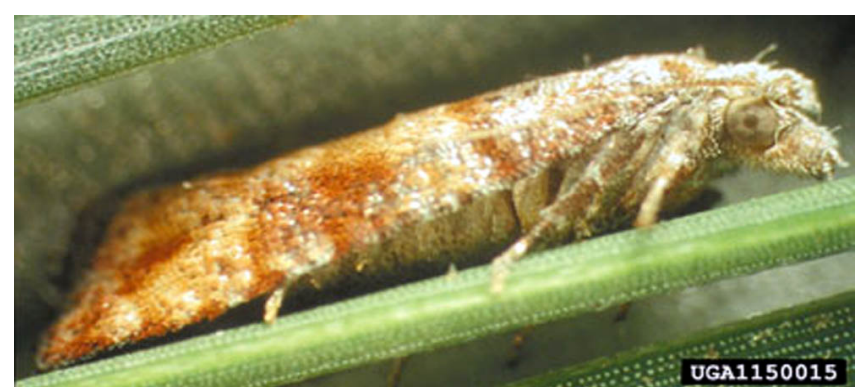

Figure 1. Adult Nantucket pine tip moth, Rhyacionia frustrana (Comstock). Credits: Photograph by: Christopher Asaro, University of Georgia, www.Forestryimages.org

of California was traced to shipment of infested seedlings from Georgia in 1967 (Yates et al. 1981).

\section{Description}

Adult: The adult female is larger than the male. Heads, bodies, and appendages covered with gray scales; mottled rusty-red forewing markings, dark basal patch bordered by a lighter crossband that is narrower than the basal patch; male forewing 4.0 to $7.0 \mathrm{~mm}$ long, female forewing 4.0 to $7.5 \mathrm{~mm}$ (Powell and Miller 1978).

\footnotetext{
1. This document is EENY-304 (originally published as DPI Entomology Circular 298), one of a series of Featured Creatures from the Entomology and Nematology Department, Florida Cooperative Extension Service, Institute of Food and Agricultural Sciences, University of Florida. Published: August 2003. This document is also available on Featured Creatures Website at http://creatures.ifas.ufl.edu. Please visit the EDIS Website at http://edis.ifas.ufl.edu. Additional information on these organisms, including many color photographs, is available at the Entomology and Nematology Department website at http://entnemdept.ifas.ufl.edu/.

2. Wayne N. Dixon, Florida Department of Agriculture and Consumer Services, Division of Plant Industry, Gainesville, FL.
}

The Institute of Food and Agricultural Sciences (IFAS) is an Equal Employment Opportunity - Affirmative Action Employer authorized to provide research, educational information and other services only to individuals and institutions that function without regard to race, creed, color, religion, age, disability, sex, sexual orientation, marital status, national origin, political opinions or affiliations. For information on obtaining other extension publications, contact your county Cooperative Extension Service office. Florida Cooperative Extension Service/Institute of Food and Agricultural Sciences / University of Florida / Larry R. Arrington, Interim Dean 


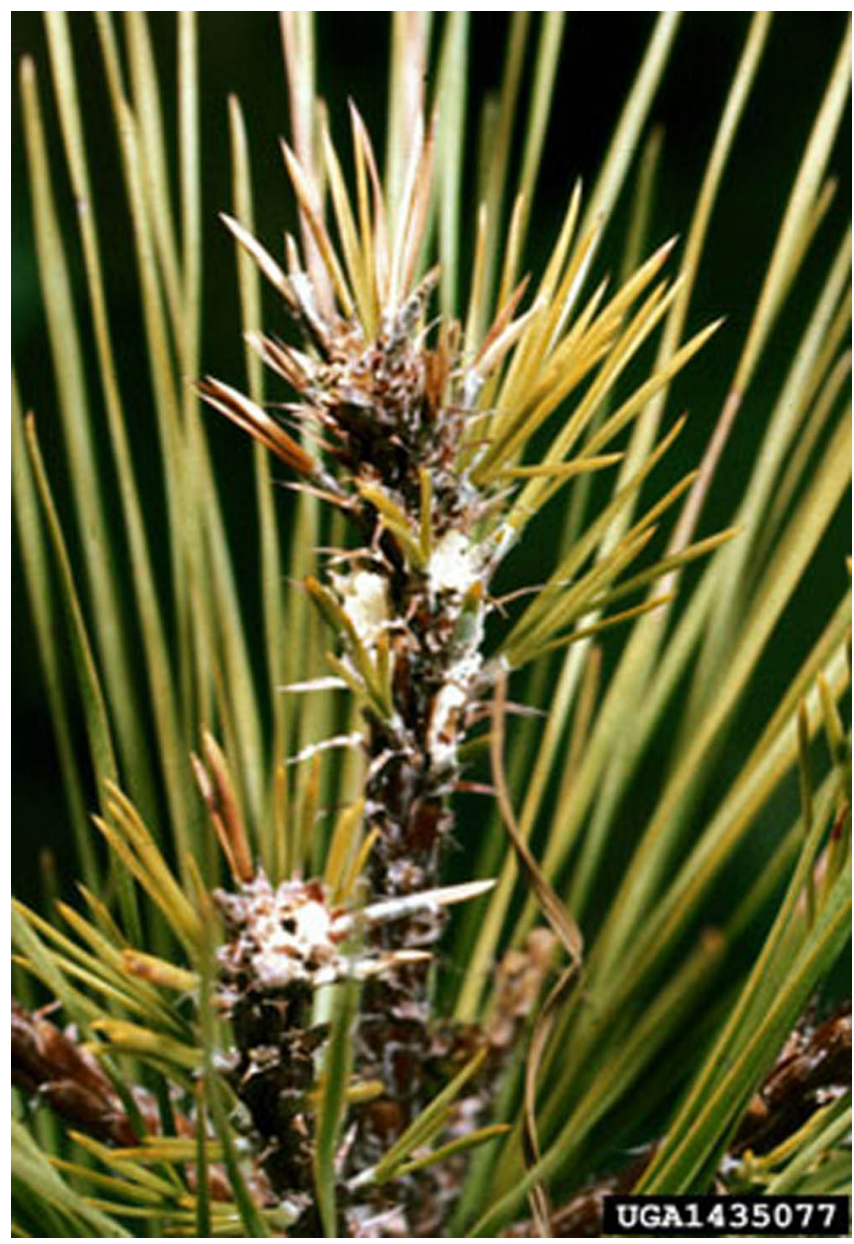

Figure 2. Damage caused by the Nantucket pine tip moth, Rhyacionia frustrana (Comstock). Credits: Photograph by: Clyde S. Gorsuch, Clemson University,

www.Forestryimages.org

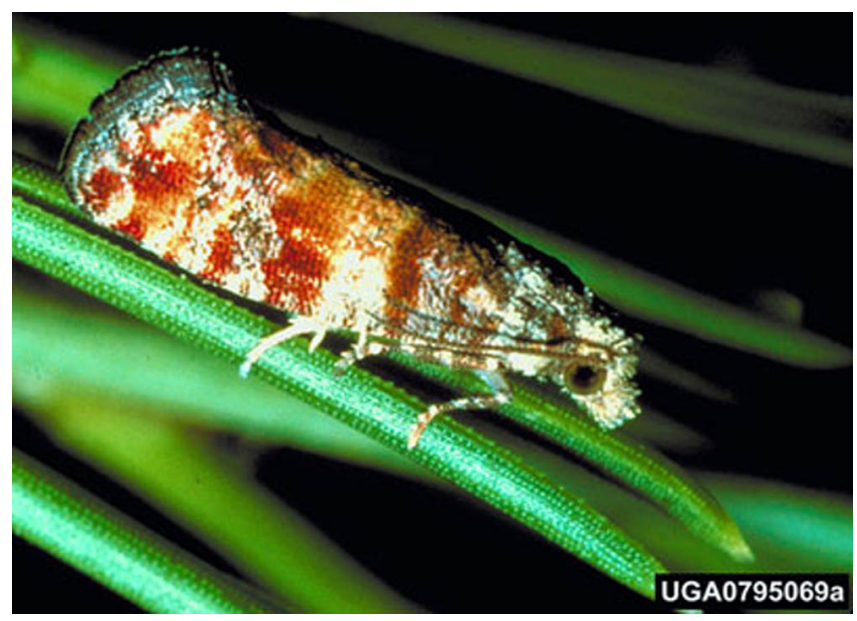

Figure 3. Adult Nantucket pine tip moth, Rhyacionia frustrana (Comstock). Credits: Photograph by: James A. Richmond, USDA Forest Service, www.Forestryimages.org

Egg: The egg is slightly convex and $0.8 \mathrm{~mm}$ in diameter; opaque white at oviposition, turning yellow to medium green at maturation.
Larva: Young larva cream-colored with black head; older larva light brown to orange; extra seta on abdominal segments 1 to 8 are posterodorsal, posterior, or posteroventral to the spiracle, spatulate spinneret; approximately $9 \mathrm{~mm}$ long when mature (MacKay 1959, Yates et al. 1981).

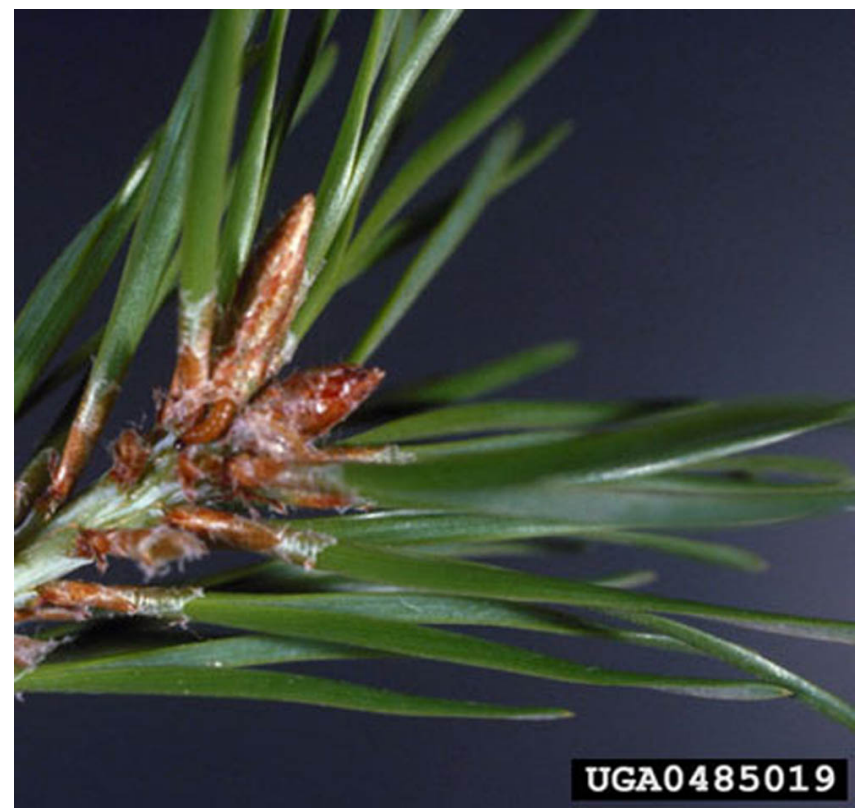

Figure 4. Larva of the Nantucket pine tip moth, (Comstock), feeding at the base of a needle. Credits: Photograph by: David J. Moorhead, University of Georgia, www.Forestryimages.org

Pupa: The pupa are light to dark brown; area below tip of frontal horn extending between eyes convex and generally smooth; vertex of pupa not exceeding tip of frontal horn; approximately 4.6 to 7.5-mm long (Yates 1969). Yates (1969) and Powell and Miller (1978) provide characters to separate adults and pupae of $R$. frustrana, Rhyacionia rigidana (Fernald) (pitch pine tip moth), and Rhyaciona subtropica (Miller) (subtropical pine tip moth), three species with overlapping host and geographic ranges.

\section{Biology}

\section{$R$. frustrana overwinters as pupae inside} damaged shoots, cones, or buds. Moths emerge in the early spring, sometimes as early as February in Florida, when warm days become common. The moths mate and females oviposit eggs on new pine shoots and conelets or last year's shoots. In cool weather (late winter or early spring), eggs may take 30 days to hatch, but require only five to 10 days to 


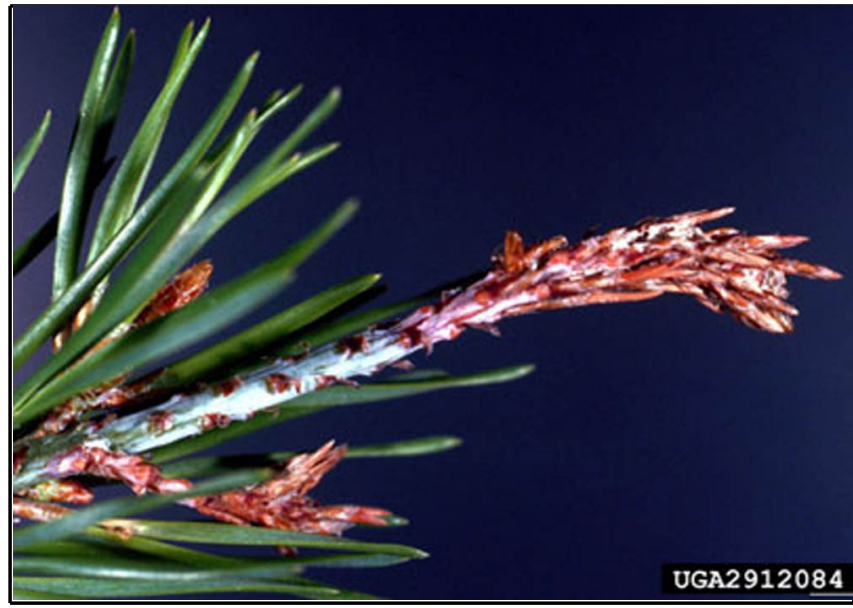

Figure 5. Pupal case of the Nantucket pine tip moth, Rhyacionia frustrana (Comstock). Credits: Photograph by: David J. Moorhead, University of Georgia, www.Forestryimages.org

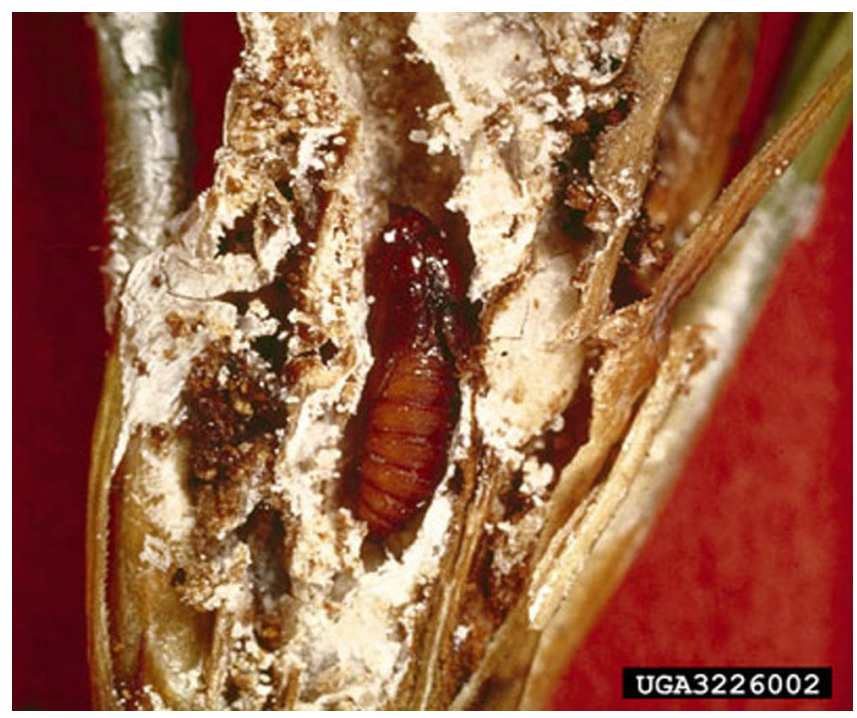

Figure 6. Pupae of the Nantucket pine tip moth, Rhyacionia frustrana (Comstock), inside a pine shoot. Credits: Photograph by: Ronald F. Billings, Texas Forest Service, www.Forestryimages.org

hatch in hot weather (late summer). After hatching from eggs, young larvae may feed on the outside of new growth for a short period of time. Later, larvae bore into shoot tips, conelets, and buds. Larval feeding within these tissues continues for three to four weeks. Pupation occurs in damaged tissues. There may be up to four to five generations per year in Florida depending on temperatures, with cool weather prolonging the time required for the life cycle, and warm weather quickening it (Yates et al. 1981).

\section{Hosts}

Nearly 20 species of pine have been recorded as host trees for $R$. frustrana: Caribbean (P. caribaea Morelet), Cuban (P. cubensis Griseb.), jack ( $P$. banksiana Lamb.), loblolly (P. taeda L.), lodgepole (P. contorta Dougl.), Monterey (P. radiata D. Don), oocarp (P. oocarpa Schiede), pitch (P. rigida Mill.), pond (P. serotina Michx.), ponderosa (P. ponderosa Laws.), red ( $P$. resinosa Ait.), sand ( $P$. clausa (Chapm.) Vasey)), Scotch (P. sylvestris L.), shortleaf ( $P$. echinata Mill.), slash ( $P$. elliottii Englem. ver. elliotti), sonderegger (X sondereggeri H.H. Chapm.), spruce ( $P$. glabra Walt.), Table-Mountain ( $P$. pungens Lamb.), and Virginia (P. virginiana Mill.) (Hedlin et al. 1981). Pine species with multinodal growth in a single season are especially favorable hosts (Yates et al. 1981).

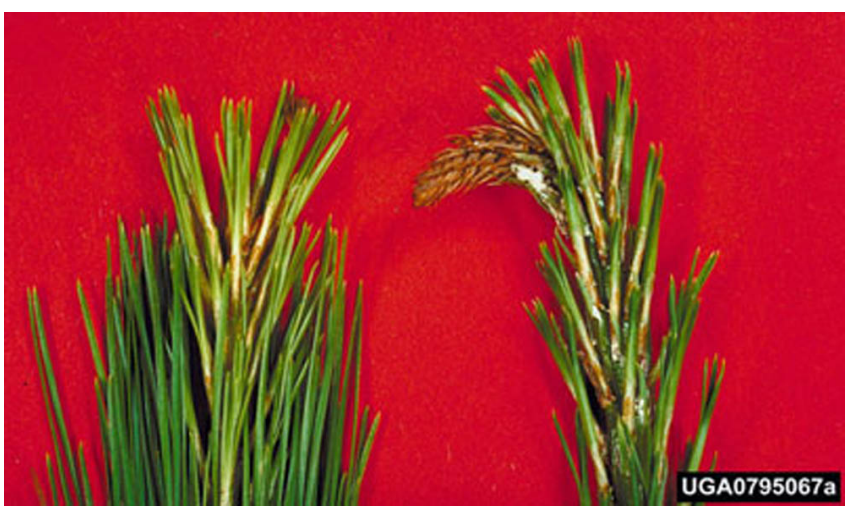

Figure 7. A comparison of healthy and infested pine shoots. Damage is caused by an infestation of the Nantucket pine tip moth, Rhyacionia frustrana (Comstock). Credits: Photograph by: Robert L. Anderson, USDA Forest Service, www.Forestryimages.org

\section{Survey and Detection}

Foliage discoloration occurs as needles turn from green to reddish-brown and subsequently fall off the shoot; dead or dying branch tips, often curved or tipped; resin beads or flakes and fine silk webbing on branch tips; and damaged parts hollowed out. Larvae or pupae may be present (Yates et al. 1981, Hedlin et al. 1981).

\section{Management}

Preventive: Plant pine species appropriate to site to minimize stress and encourage thrifty growth; promote early crown closure within a plantation; 


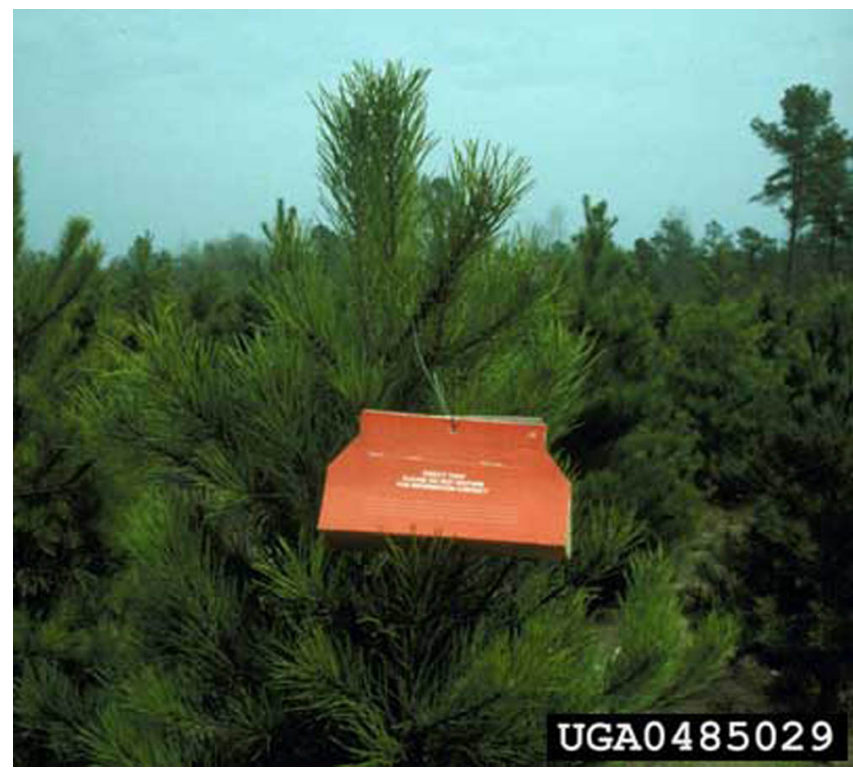

Figure 8. Pheromone trap used to survey the Nantucket pine tip moth, Rhyacionia frustrana (Comstock). Credits: Photograph by: David J. Moorhead, University of Georgia, www.Forestryimages.org

allow weed growth in a plantation to promote populations of natural enemies; plant non-preferred species of pines.

Remedial: Hand-prune infested shoots and conelets if level of infestation is minor and branches are within reach; apply a registered insecticide. Employ pheromone traps, specific to $R$. frustrana, to optimize timing of insecticide application (Gargiullo et al. 1983).

Insect Management Guide for commercial forest trees: pines and cypress (http://edis.ifas.ufl.edu/ IG058)

Insect Management Guide for forest tree nurseries and young trees: pines and cedars (http://edis.ifas.ufl.edu/IG055)

Insect Management Guide for Christmas trees: pines and cedars (http://edis.ifas.ufl.edu/IG056)

\section{Selected References}

Gargiullo PM., Berisford CW, Canalos CG, Richmond JA. 1983. How to time dimethoate sprays against the Nantucket pine tip moth. Georgia Forestry Commission., Georgia Forestry Research Paper 44. $10 \mathrm{pp}$.
Hedlin AF, Yates III HO, Tovar DC, Ebel BH, Koerber TW, Merkel EP. 1981. Cone and seed insects of North American conifers. USDA Forest Service. $122 \mathrm{pp}$.

MacKay MR. 1959. Larvae of the North American Olethreutidae (Lepidoptera). Canadian Entomologist Supplement 10. 338 pp.

Powell JA, Miller WE. 1978. Nearctic pine tip moths of the genus Rhyacionia: Biosystematic review. USDA Forest Service Agricultural Handbook No. 514. 51 pp.

Yates III. HO. 1969. Pupae of Rhyacionia frustrana, $R$. rigidana, and $R$. subtropica (Lepidoptera: Olethreutidae). Annals of the Entomological Society of America 60: 1096-1099.

Yates III HO, Overgaard NA, Koerber TW. 1981. Nantucket pine tip moth. USDA Forest Service, Forest Insect \& Disease Leaflet 70.7 pp. 